\title{
POPULATION DENSITY OF Thrips tabaci Lindeman ON ONION IN RELATION TO PALNTING DISTANCES, INTERCOROPPING SYSTEMS WITH GARLIC VARITIES, AND YIELD
}

\begin{abstract}
Hamdy H. Mahmoud
Plant Protection Research Institute, Agricultural Research Center, Dokki, Giza, Egypt

ABSTRACT

The present study was conducted to determine the effect of planting distances $(5,10$ and $15 \mathrm{~cm}$.), intercropping with onion plants and two garlic varieties (Egyptian and Chinese) on population fluctuation of Thrips tabaci Lindeman on onion plants during two successive seasons (2017/2018 and 2018 / 2019) in Assiut Governorate, Egypt. Results indicated that the three mentioned variables showed significant results on the population of $T$. tabaci. The plant distances were the most significant factor, with the highest numbers of thrips closest spacing $(5 \mathrm{~cm}$.) between plants. The intercropped garlic with onion showed that the garlic harbored lowest numbers of the pest. Meanwhile, in onion solo the density of pest was higher in onion compared to intercropped one with garlic. Onion with Egyptian garlic variety showed lower numbers of the pest than the onion with chinese garlic variety. The highest yield of onions was gained when the distance between plants was $(10 \mathrm{~cm}$.). However, onions loaded with garlic showed lower yield than onions grown separately during the seasons of study.
\end{abstract}

Keywords: Onion, garlic, planting distances, intercropping with garlic varieties, Thrips tabaci, population, yield.

\section{INTRODUCTION}

In Egypt, onion (Allium cepa L.) is an important field crop for local consumption and exportation. Onion plantations are subjected to infestation with various insect pests that affect crop quality and quantity (Mahmoud, 2008). Onion plantations are target for insect pests attack throughout their different growth stages. However, onion plantations are subject to be infested by among which dominate Thrips tabaci Lindeman (Thysanoptera: Thripidae) in onion fields. According to the statistics of the Ministry of Agriculture and Land Reclamation the total area cultivated with garlic in Assiut Governorate in 2018 exceeded 3743 feddan.
Recently, great attention has been given to increase cultivated area of onion. Increasing the crop production could be achieved by planting heavy yielding varieties and / or improving the agricultural practices (Nassar et al., 1972) and Foda et al., 1977). Onion thrips T. tabaci is one of the main insect pests infesting onion crops causing severe damage by it always reduces the yield (El-Sherif, 1971) and (Shoeib and Hosny, 1972) in Egypt reported that $T$. tabaci was the major insect pest attacking onion plants. Also, Abd-El- Wahab (2004) reported that Thrips tabaci occurs on all Alliaceae crops. This pest is a worldwide one and has an extensive host range that 
includes more than 200 plant species in Egypt include the works of Karaman (1970), Khalil et al. (1971), Haydar and Sherif (1987), Abd El-Ghany (1997), El-Gendi (1998), Salman(2000), Massry (2002), Sabra et al. (2007), Mahmoud (2008), El-Sherif and Mahmoud (2008), Amro et al. (2009), Awadalla et al. (2011) and El-Fakharany et al. (2012). Relevant investigations abroad include the studies of El-Serwiy et al. (1985) in Iraq, Kalafchi et al. (2006) in Iran Edelson et al. (1986), Duchovskiene (2006), John Diaz et al. (2011) and Elaine et al. (2014) in USA, Lu and Lee (1987) in Taiwan, Lorine and Dunicr (1988) in Brazil , Maher \&Shafiq (2014), Neetu \& Virendra (2016) in India and Tadele \& Amin (2014), Gebretsadkan (2017) in Ethiopia.

Most of investigations dealed with biology and ecology of T. tabaci, while little attention was given to the effect of some agricultural practices on the onion thrips infestations. The present study was undertaken to study the effect of different planting distances of onion, and intercropping onion plantations with two garlic varieties on the density of $T$. tabaci with reference to onion yield.

\section{MATERIALS AND METHODS}

This work was carried out in selected farmer fields planted with the commonly grown onion cultivar "Giza 6 Mohassan" at Assiut Governorate during the two successive onion growing seasons of 2017 /2018 and 2018 / 2019. An area of about 1/4 feddan was divided into three experiments. onion were sown on earlyNovember. Each experiment was designed in (RCBD) randomized complete block design with four replications. The first experiment for investigate different planting distances (5, 10 and $15 \mathrm{~cm}$.). The second experiment used for study the effect of intercropping of onion plants with garlic varieties (1 : 1, onion : garlic Egyptian and Chinese varieties alternate rows compared with sole onion). Normal agricultural practices of growing onion were followed and no insecticides were applied during the study period. One month after planting, five onion plants were collected from replicate at quarter - monthly intervals, thus making a total sample size of 20 plants from the whole treatment. Samples were collected at 7-8 a.m. from the beginning of December until the early of April. Samples were introduced into clean cloth bags, and then transferred to the laboratory where they were examined for the occurrence and count the adults and larvae of Thrips. The obtained data were statistically analyzed for variance according to Sndecor and Cochran (1967). The mean values were compared at $5 \%$ levels of least significant differences, for each season.

\section{RESULTS AND DISCUSSION}

The mean numbers of the pest in each treatment were counted and recorded in Tables $(1,2,3$, and 4). The effect of the three factors (i. e. planting distances of onion, intercropping with two garlic varieties) on the population density of $T$. tabaci on onion plants during the two successive seasons were presented as follows:

1. Planting distances of onion and population density of $T$. tabaci:

The planting distance affected significantly the mean numbers of $T$. tabaci infesting garlic plants (Table 1). The mean numbers of $T$. tabaci per plant in 2017 / 
2018 season were $302.0,263.7$ and 208.2 individuals / plant, when planted 5, 10 and $15 \mathrm{~cm}$. apart, respectively. In the second season (2018 / 2019) the corresponding means were high than those of the first season (327.4, 262.9 and 219.1 individuals / plant) in onion plants. Statistical analysis of thrips numbers per onion plant at the three planting distances produced highly significant differences between the mean numbers of thrips at tested planting distances in the both seasons. The results indicated that the widest distances for planting garlic of $(15 \mathrm{~cm}$.) led to the lowest infestation levels by $T$. tabaci in both seasons (208.2 and 219.1) thrips individuals / plant, during two seasons, respectively. Whereas the highest numbers of thrips closest spacing $(5 \mathrm{~cm}$.) between plants $(302.0$ and 327.4) thrips individuals / plant, during two seasons, respectively. While there was a distance of $(10 \mathrm{~cm}$.) between onion plants with moderate infestation, where thrips numbers were recorded (263.7 and 262.9) individuals / plant, during the two seasons, respectively. Similar results were reported by Abd El- Ghany (1997), Maksoud et al. (1983) and Mahmoud (2014) who found that, increasing the crop production of onion could be achieved by planting at wider space.

Table (1): Effect of planting distances of onion on the population of $T$. tabaci, during two seasons in Assiut Governorate, Egypt.

\begin{tabular}{|c|c|c|c|c|c|c|c|}
\hline \multirow{2}{*}{\multicolumn{2}{|c|}{ Inspection $\begin{array}{c}\text { Planting } \\
\text { date }\end{array}$}} & \multicolumn{6}{|c|}{ Mean number of T. tabaci / plant } \\
\hline & & 5 & 10 & 15 & 5 & 10 & 15 \\
\hline Month & Quarter & \multicolumn{3}{|c|}{$2017 / 2018$} & \multicolumn{3}{|c|}{$2018 / 2019$} \\
\hline \multirow{4}{*}{ Dec. } & 1 & 1.3 & 1.1 & 0.9 & 1.9 & 1.5 & 1.6 \\
\hline & 2 & 2.5 & 2.3 & 1.3 & 2.3 & 2.8 & 1.9 \\
\hline & 3 & 2.9 & 2.5 & 2.8 & 5.5 & 3.7 & 3.3 \\
\hline & 4 & 4.1 & 4.2 & 2.9 & 5.1 & 5.7 & 2.9 \\
\hline \multirow{4}{*}{ Jan. } & 1 & 7.4 & 6.5 & 5.4 & 4.8 & 4.7 & 4.4 \\
\hline & 2 & 5.9 & 8.5 & 6.2 & 8.4 & 4.6 & 5.7 \\
\hline & 3 & 12.8 & 8.9 & 12.1 & 13.7 & 9.4 & 8.8 \\
\hline & 4 & 13.4 & 12.7 & 8.4 & 16.9 & 13.8 & 7.6 \\
\hline \multirow{4}{*}{ Feb. } & 1 & 16.0 & 15.6 & 13.3 & 27.8 & 20.4 & 12.6 \\
\hline & 2 & 21.5 & 20.8 & 20.2 & 34.6 & 25.0 & 18.1 \\
\hline & 3 & 24.5 & 23.9 & 16.0 & 33.2 & 27.4 & 22.7 \\
\hline & 4 & 29.5 & 25.6 & 19.2 & 41.8 & 35.8 & 34.6 \\
\hline \multirow{4}{*}{ March } & 1 & 39.6 & 31.4 & 26.4 & 37.1 & 34.2 & 29.9 \\
\hline & 2 & 51.8 & 42.9 & 33.6 & 45.3 & 32.2 & 28.4 \\
\hline & 3 & 39.7 & 33.8 & 22.2 & 25.8 & 17.8 & 18.7 \\
\hline & 4 & 15.6 & 12.0 & 9.4 & 15.6 & 14.3 & 11.4 \\
\hline April & 1 & 13.5 & 11.0 & 7.9 & 7.6 & 9.6 & 6.5 \\
\hline \multicolumn{2}{|c|}{ Total } & $302.0 \mathrm{a}$ & $263.7 \mathrm{~b}$ & $208.2 \mathrm{c}$ & $327.4 \mathrm{a}$ & $262.9 \mathrm{~b}$ & $219.1 \mathrm{c}$ \\
\hline \multicolumn{2}{|c|}{$\begin{array}{c}\mathbf{F} .(\mathbf{0 . 0 5}) \\
\text { Between treatments }\end{array}$} & \multicolumn{3}{|c|}{$39.89 * *$} & \multicolumn{3}{|c|}{$27.54 * *$} \\
\hline \multicolumn{2}{|c|}{$\begin{array}{c}\text { L.S.D. }(\mathbf{0 . 0 5}) \\
\text { Between treatments }\end{array}$} & \multicolumn{3}{|c|}{9.36} & \multicolumn{3}{|c|}{11.89} \\
\hline
\end{tabular}

${ }^{*}$ Significant at $5 \%$ level of probability 
2- Planting distances and population density of T. tabaci, and yield:

Data in Table (2) and Fig. (1) showed that, plant distance $(10 \mathrm{~cm}$.) gave the highest total yield (14.235 and 13.875 ; out of total mean 14.055 ton / fed. of both seasons; respectively). However, $(5 \mathrm{~cm}$.) distance gave the lowest value (11.915 and 11.584 out of total mean 11.7495 ton / fed. of both seasons; respectively). The present results are in agreement with those obtained by [ Stoffella et al. (2000), Kanton et al. (2003), Nasir et al. (2007), Amro et al. (2009), Xingang Zhou et al. (2011), Haider et al. (2014), Bleasdale (2015), McGeary (2015), Harsimran et al. (2015), Maher et al. (2017). who reported that the increase in plant density resulted reduction in plant size, mean bulb weight, plant fresh and dry weights and number of leaves.

Table ( 2 ): Effect of planting distances of onion plants and population density of T.tabaci, on yield ( ton / fed ) in during 2017 /2018 and 2018 / 2019 seasons at Assiut Governorate.

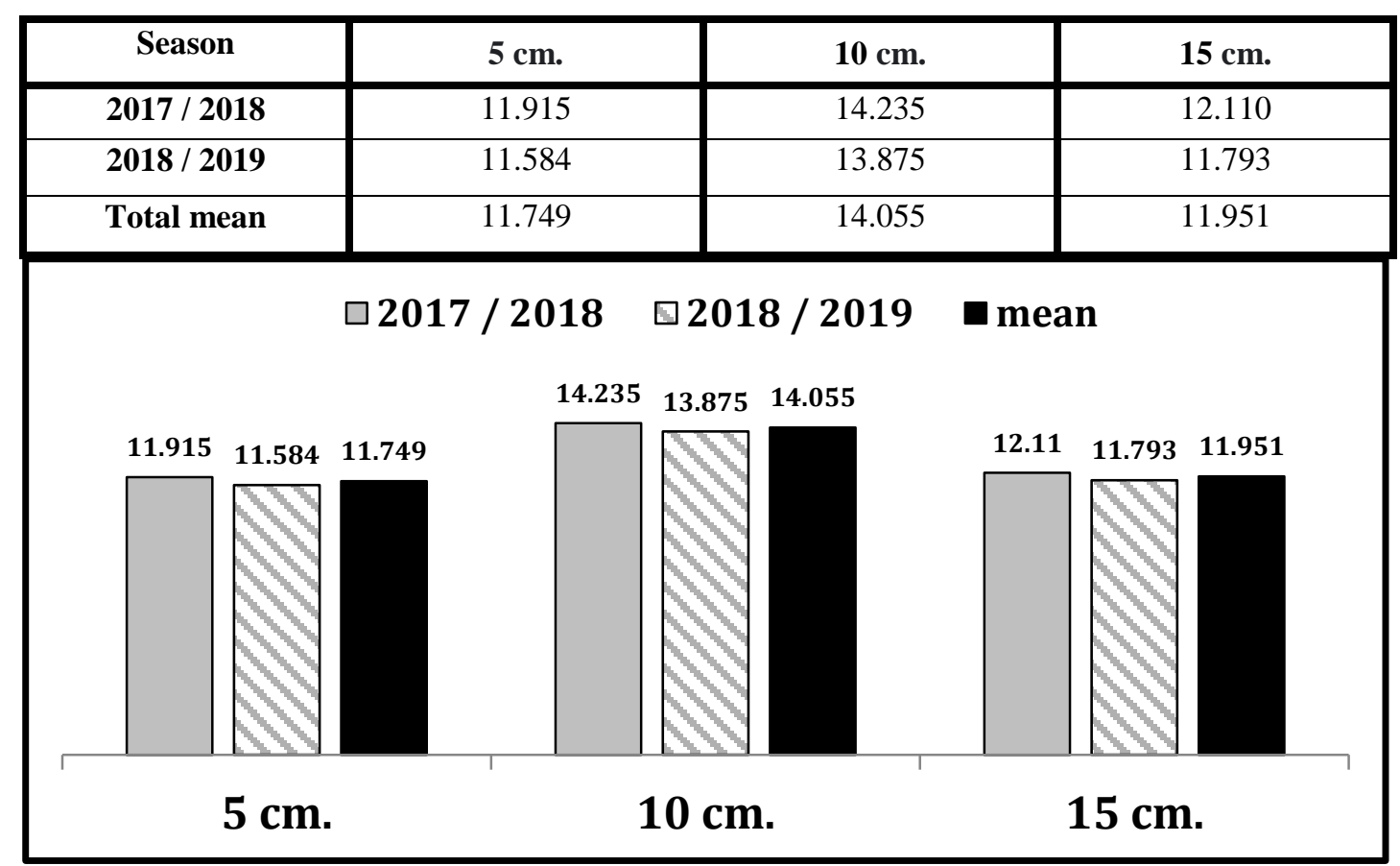

Fig. ( 1 ): Effect of planting distances of onion plants and the population density of T. tabaci, on yield ( ton / fed ) during 2017 /2018 and 2018 / 2019 seasons at Assiut Governorate.

3- Effect of intercropping of onion plants with garlic varieties on the population density of $T$. tabaci:

The effect of intercropping of onion with garlic plants on T. tabaci population
(Table 3). Showed that the high significant differences in 
Table (3): Effect of intercropping of onion plants with garlic varieties (Egyptian and Chinese) on the population of $T$. tabaci compared with the solely onion plants, during 2017 /2018 and 2018 / 2019 seasons at Assiut Governorate.

\begin{tabular}{|c|c|c|c|c|c|c|c|c|c|}
\hline \multirow{2}{*}{\multicolumn{2}{|c|}{ Inspection }} & \multicolumn{8}{|c|}{ Mean number of T. tabaci / plant } \\
\hline & & \multicolumn{2}{|c|}{$\begin{array}{c}\text { Onion with } \\
\text { Egyptian Garlic }\end{array}$} & \multicolumn{2}{|c|}{ Onion solely } & \multicolumn{2}{|c|}{$\begin{array}{c}\text { Onion with } \\
\text { Chinese Garlic }\end{array}$} & \multicolumn{2}{|c|}{ Onion solely } \\
\hline Month & Quarter & $\begin{array}{c}2017 / \\
2018\end{array}$ & $\begin{array}{c}2018 / \\
2019\end{array}$ & $\begin{array}{c}2017 / \\
2018\end{array}$ & $\begin{array}{c}2018 / \\
2019\end{array}$ & $\begin{array}{c}2017 / \\
2018\end{array}$ & $\begin{array}{c}2018 / \\
2019\end{array}$ & $\begin{array}{c}2017 / \\
2018\end{array}$ & $\begin{array}{c}2018 / \\
2019\end{array}$ \\
\hline \multirow{4}{*}{ Dec. } & 1 & 0.6 & 0.9 & 1.0 & 1.4 & 0.8 & 0.7 & 1.2 & 1.1 \\
\hline & 2 & 1.3 & 1.5 & 1.7 & 2.1 & 1.5 & 1.3 & 2.2 & 2.5 \\
\hline & 3 & 1.7 & 1.9 & 2.9 & 3.5 & 1.6 & 1.3 & 3.8 & 4.9 \\
\hline & 4 & 1.9 & 2.2 & 4.1 & 3.8 & 2.6 & 2.7 & 9.4 & 11.2 \\
\hline \multirow{4}{*}{ Jan. } & 1 & 2.6 & 2.6 & 7.3 & 4.7 & 2.8 & 4.3 & 12.0 & 15.2 \\
\hline & 2 & 3.1 & 2.7 & 5.8 & 6.4 & 4.2 & 6.4 & 19.3 & 20.0 \\
\hline & 3 & 4.9 & 3.4 & 12.3 & 11.5 & 7.4 & 7.1 & 25.2 & 19.3 \\
\hline & 4 & 4.8 & 4.7 & 11.4 & 16.1 & 7.6 & 17.1 & 27.5 & 24.3 \\
\hline \multirow{4}{*}{ Feb. } & 1 & 5.5 & 7.0 & 14.0 & 26.4 & 11.2 & 12.2 & 47.6 & 34.2 \\
\hline & 2 & 6.3 & 7.9 & 19.5 & 27.6 & 19.1 & 16.0 & 48.1 & 32.5 \\
\hline & 3 & 6.9 & 9.8 & 25.5 & 30.2 & 23.2 & 14.0 & 47.7 & 44.7 \\
\hline & 4 & 9.0 & 8.9 & 32.5 & 39.4 & 32.5 & 17.5 & 57.2 & 49.5 \\
\hline \multirow{4}{*}{ Mar. } & 1 & 8.9 & 11.5 & 39.4 & 36.1 & 31.2 & 27.0 & 55.7 & 44.4 \\
\hline & 2 & 5.5 & 7.6 & 37.3 & 38.2 & 16.8 & 17.7 & 49.0 & 47.7 \\
\hline & 3 & 5.7 & 8.9 & 29.6 & 25.8 & 11.9 & 10.2 & 21.1 & 36.8 \\
\hline & 4 & 4.5 & 6.1 & 11.9 & 13.6 & 8.4 & 11.4 & 15.7 & 27.4 \\
\hline April & 1 & 1.7 & 2.3 & 9.8 & 8.4 & 4.8 & 5.3 & 12.5 & 12.9 \\
\hline \multicolumn{2}{|c|}{ Total } & 74.9 & 93.6 & 266 & 295.2 & 187.6 & 172.2 & 455.2 & 428.6 \\
\hline \multicolumn{2}{|c|}{$\begin{array}{c}\text { F. }(\mathbf{0 . 0 5}) \\
\text { Between treatments }\end{array}$} & \multicolumn{4}{|c|}{$365.2 * *$} & \multicolumn{4}{|c|}{$321.7 * *$} \\
\hline \multicolumn{2}{|c|}{$\begin{array}{c}\text { L.S.D. }(\mathbf{0 . 0 5}) \\
\text { Between treatments }\end{array}$} & \multicolumn{4}{|c|}{6.48} & \multicolumn{4}{|c|}{8.57} \\
\hline
\end{tabular}

Significant at $5 \%$ level of probability

onion characters in mono and maxed cultures during 2017 / 2018 and 2018 / 2019, seasons. Similar results were recorded in both varieties (onion with garlic Egyptian and garlic Chinese) during both seasons. Also, data illustrated in Table (3) showed that, the rate of infestation was higher on the sole onion plants $[(266 \&$ 295.2) and (74.9 \& 93.6) individuals / plant] compared with intercropping Egyptian garlic, respectively in both seasons. The same trend was noticed throughout the Chinese garlic variety. The results indicate that the rate of infestation was higher on the sole onion than on these intercropped with Chinese garlic plants $[(455.2 \& 428.6)$ and $(187.6 \& 172.2)$ individuals / plant] compared with intercropping garlic Chinese, respectively in both seasons. Generally the obtained data indicated that the lowest mean of $T$. tabaci occurred in the intercropped onion plants with two garlic varieties in both seasons.

4- Effect of intercropping of onion plants with garlic varieties and the population density of $T$. tabaci, on yield: The data presented in (Table 4; Fig.

2) showed decrease in all results of yield due to intercropping onion on Egyptian garlic and onion on Chinese garlic (7.412 and 6.724 ton / fed.) in season 2017 / 2018. Also, gave the result in season 2018 / 2019 (7.220 and 6.820 ton / fed.), respectively for Egyptian and Chinease variety. The highest values of yield were observed in onion solely 
during the seasons $(14.343,13.975$ and

13.910, 13.678 ton / fed. respectively for the

first and second season). Similar results are in agreement with the findings of Stanislav

Trdan et al.(2006) and Abou-Keriasha et al.

(2013).

Table ( 4 ):Effect of intercropping of onion plants with garlic varieties and the population density of T. tabaci, on yield (ton / fed) during 2017 / 2018 and 2018 / 2019 seasons at Assiut

Governorate.

\begin{tabular}{|c|c|c|c|c|}
\hline Season & $\begin{array}{c}\text { Onion with } \\
\text { Egyptian Garlic }\end{array}$ & Onion solely. & $\begin{array}{c}\text { Onion with } \\
\text { Chinese Garlic }\end{array}$ & Onion solely \\
\hline $\mathbf{2 0 1 7} / \mathbf{2 0 1 8}$ & 7.412 & 14.343 & 6.724 & 13.910 \\
\hline $\mathbf{2 0 1 8}$ / 2019 & 7.220 & 13.975 & 6.820 & 13.678 \\
\hline Total mean & 7.316 & 14.159 & 6.772 & 13.794 \\
\hline
\end{tabular}

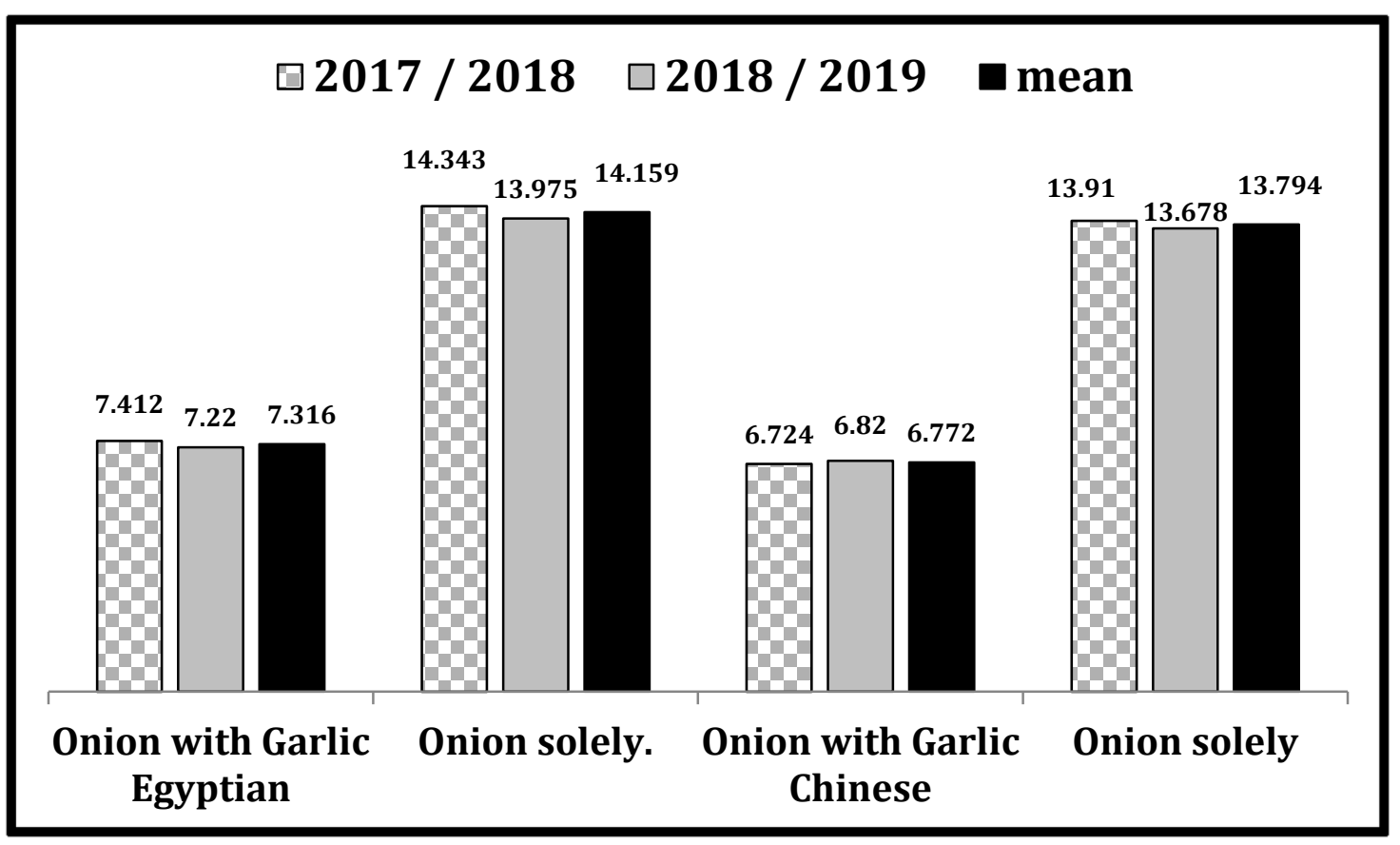

Fig. ( 2 ):Effect of intercropping of onion plants with garlic varieties and the population density of Thrips tabaci, on yield (ton / fed) during 2017 / 2018 and 2018 / 2019 seasons at Assiut

\section{Governorate.}

5- Effect of garlic varieties on the population density of T. tabaci:

Both garlic varieties showed highly susceptible to the infestation by $T$. tabaci (Table 5).. At the beginning of the season, means of thrips individuals on garlic plants started with low fluctuation numbers ranged from 1.1- 1.4 individuals / plant of Egyptian variety and 1.6 - 1.8 on Chinese variety. The individuals of $T$. tabaci increased gradually throughout the growing period of both varieties. The highest denesity of thrips was detected during the period from February till harvesting. These results may be confirmed those previously reported by Lorine and Dunicr (1988), in Brazil, who indicated that with low T. tabaci infestation rate to garlic plants (less than 1.0 means of individuals/ plant) occurred at early time, then infestation increased to reach 174.6 means of individuals / plant. Additionally, similar results were reported 
by Abd El-Ghany (1997), Massry (2002), El-

Fakharany et al. (2012) and Mahmoud (2014) in Egypt, whom indicated that the population of $T$. tabaci at the beginning of the season was in low fluctuation then increased throughout the growing season (Extending from February to end of the season).

Table (5): Effect of garlic varieties on the population of $T$. tabaci, during 2017 / 2018 and 2018 / 2019 seasons at Assiut Governorate.

\begin{tabular}{|c|c|c|c|c|c|}
\hline \multirow{2}{*}{\multicolumn{2}{|c|}{$\begin{array}{c}\begin{array}{c}\text { Inspection } \\
\text { date }\end{array} \\
\text { Garlic } \\
\text { Varieties }\end{array}$}} & \multicolumn{4}{|c|}{ Mean number of $T$. tabaci / plant } \\
\hline & & Egyptian Garlic & Chinese Garlic & Egyptian Garlic & Chinese Garlic \\
\hline Month & Quarter & \multicolumn{2}{|c|}{$2017 / 2018$} & \multicolumn{2}{|c|}{2018 / 2019} \\
\hline \multirow{4}{*}{ Dec. } & 1 & 1.1 & 1.6 & 1.4 & 1.8 \\
\hline & 2 & 1.7 & 2.4 & 2.0 & 3.6 \\
\hline & 3 & 2.9 & 3.4 & 3.5 & 5.5 \\
\hline & 4 & 5.1 & 7.4 & 3.9 & 12.2 \\
\hline \multirow{4}{*}{ Jan. } & 1 & 7.3 & 12.0 & 6.3 & 13.7 \\
\hline & 2 & 9.5 & 15.3 & 6.4 & 20.3 \\
\hline & 3 & 12.3 & 27.2 & 11.8 & 19.3 \\
\hline & 4 & 11.4 & 24.5 & 16.1 & 30.3 \\
\hline \multirow{4}{*}{ Feb. } & 1 & 17.0 & 39.6 & 25.4 & 33.2 \\
\hline & 2 & 21.5 & 45.1 & 32.6 & 36.5 \\
\hline & 3 & 27.3 & 53.3 & 30.2 & 42.7 \\
\hline & 4 & 32.2 & 55.2 & 41.6 & 46.7 \\
\hline \multirow{4}{*}{ Mar. } & 1 & 39.5 & 53.7 & 36.1 & 44.1 \\
\hline & 2 & 41.4 & 40.0 & 42.4 & 41.5 \\
\hline & 3 & 31.7 & 21.2 & 24.9 & 36.3 \\
\hline & 4 & 11.5 & 13.8 & 14.7 & 17.6 \\
\hline April & 1 & 11.1 & 12.1 & 9.2 & 12.8 \\
\hline \multicolumn{2}{|c|}{ Total } & 284.5 & 427.8 & 308.5 & 418.1 \\
\hline \multicolumn{2}{|c|}{$\begin{array}{c}\text { F. }(\mathbf{0 . 0 5}) \\
\text { Between treatments }\end{array}$} & \multicolumn{2}{|c|}{$120.3 * *$} & \multicolumn{2}{|c|}{$59.34 * *$} \\
\hline \multicolumn{2}{|c|}{$\begin{array}{c}\text { L.S.D.(0.05) } \\
\text { Between treatments }\end{array}$} & \multicolumn{2}{|c|}{10.02} & \multicolumn{2}{|c|}{10.86} \\
\hline
\end{tabular}

Significant at $5 \%$ level of probability

Finally, it can be concluded that the tested garlic varieties showed different significance in their susceptibility to pest inavsion. The whole season mean numbers of thrips on Egyptian variety were 284.5 and 308.5 individuals per plant in 2017 / 2018 and 2018 / 2019 seasons, respectively. The corresponding counts on the Chinese variety were 427.8 and 418.1 individuals per plant, respectively for the same mentioned order of seasons. The differences of these counts on plants of the two varieties were significant. Generally the obtained data indicated that the lowest mean of $T$. tabaci infestation on Egyptian variety, while the Chinese variety was the most susceptibility to the pest. The present results are in agreement with the findings of Abd ElGhany (1997) and Amro et al. (2009) in Egypt, mentioned that the differences of these counts of thrips on plants of the two garlic varieties were shown to be significant. In this regard Darshan et al. (1986) found that the varieties of onion and garlic, in the field in Punjab, showed great differences in their natural infestation by Thrips tabaci. 


\section{REFERENCES}

Abd El-Ghany, M. E. (1997). Effect of planting distances, potassium fertilizer levels and garlic varieties on the population density of Thrips tabaci Lindeman. Bull. Ent. Soc. Egypt, 75(27): 27-37.

Abd-El-Wahab, A. S. (2004). Insects and insect-borne viruses associated with Alliaceae crops in Egypt. Ph. D. Thesis, Fac. Agric., Cairo Univ., Egypt, 250 pp.

Abou-Keriasha, M. A.; Nadia, M. A. and Elwakil, N. M. H. (2013). Effects of Intercropping Faba Bean on Onion and Wheat With or Without Inoculated Bacteria on Yields of the Three Crops. Egypt. J. Agron., 35(2): 169 - 182.

Amro, M. A.; Abd El-Rahim, G. H. and Abd El-Raheem, A. A. (2009). Population fluctuation, relative susceptibility and control of Thrips tabaci Lind. on some onion and garlic cultivars and strains. Ass. Univ. Bull. Environ. Res., 12(2): $131-141$.

Awadalla, S. S.; El-Naggar, M. E.; AbdelBaky N. F. and Omnia F. H. (2011). The insect pests attacking onion plants with special references to the onion thrips thrips tabaci lind. at mansoura region. J. Plant Prot. and Path., Mansoura Univ., 2 (1): 1-12.

Bleasdale, J. K. A. (2015). The Effects of Plant Spacing on The Yield of Bulb Onions (Allium cep A L.) Grown from Seed. J. hort. Sci., 41: $145-153$.
Darshan, S.; Sihu, A. S. and Thakur, J. C. (1986). Relative resistance of onion and garlic cultivars to thrips, Thrips tabaci Lind. J. Res. Punjab, Agric. Univ., 23(3): 424427.

Duchovskienè, L. (2006). The abundance and population dynamics of onion thrips (Thrips tabaci Lind.) in leek under field conditions. Agronomy Research 4: 163-166.

Edelson, J. V.; Cartwright, B. and Royer, T. A. (1986). Distribution and impact of Thrips tabaci (Thysanoptera: Thripidae) on onion. J. Econ. Entomol., 79(1): 502-505.

Elaine, J. F.; Jessica, D. P. and Brian, A. N. (2014). Relationships between insect predator populations and their prey, Thrips tabaci, in onion fields grown in large-scale and small-scale cropping systems. Bio Control, 59: 739-748.

El-Fakharany, S. K. M.; Samy, M. A. and Hendawy, A.S. (2012). Population fluctuations of Thrips tabaci Lindeman and associated spiders in garlic plantations as influenced by weather factors and toxic compounds. Egypt. J. Agric. Res., 90(2): 1-15.

El-Gendi, S. M. (1998). Population fluctuation of Thrips tabaci Lind. on onion plants under Fayoum environmental conditions. Arab Universities J. Agric. Sci., 6(1): 267-276.

El-Serwiy, S. A.; Razoki, I. A. and Ragab, A. S. (1985). Population density of Thrips tabaci Lindeman and the 
predators Orius albidipennis Reut. and Aeolothrips fasciatus L. on onion. J. Agric. Water Reso. Res., 4(3): 57-67.

El-Sherif, A. R. A. (1971). Studies on insects infesting onion and garlic in field and storage. Ph. D. Thesis, Fac. Agric., Cairo Univ., Egypt, 279 pp.

El-Sherif, S. I. and Mahmoud, H. H. (2008). The population densities of two major insect pests of onion; the onion thrips (Thrips tabaci Lindeman) in fields and the onion bulb fly (Eumerus amoenus Loew.) in stores. Bull. Fac. Agric. Cairo Univ., 59(4): 326-332.

Foda, S. A.; El-Baz, S. A. and Moustapha, S. M. (1977). Varietal trial of garlic in Egypt. Agric. Res. Rev., 55(3): 165-175.

Gebretsadkan, Z. (2017). Seasonal distribution and abundance of Thrips (Thysanoptera: Thripidae) on onion producion in central zone of Tigray, Ethiopia. Int. J. of Life Sciences, 5 (3): 323-331.

Haider, K; Ghulam, A.; Asifa, H.; Ghayour, A. and Amjad, A. (2014). Losses in Onion (Allium cepa) Due to Onion Thrips (Thrips tabaci) (Thysanoptera: Thripidae) and Effect of Weather Factors on Population Dynamics of Thips. World Applied Sciences Journal, 32 (11): 2250-2258.

Harsimran, K. Gill; Harsh, Garg; Arshdeep, K. Gill; Jennifer, L. Gillett-Kaufman; and Brian A. Nault (2015). Onion Thrips
(Thysanoptera: Thripidae)

Biology, Ecology, and Management in Onion Production Systems. J. Integ. Pest Mngmt., 6(1): 1-9.

Haydar, M. F. and Sherif, L. S. (1987). Ecological aspects and developing method of onion pest control. Bull. Soc. Ent. Egypt, Economic Series, 16: 119-126.

John diaz, M.; Marc, F.; Brian, A. N.; Zsef, F.; and Anthony, M. S. (2011). Onion Thrips (Thysanoptera: Thripidae): A Global Pest of Increasing Concern in Onion. $J$. Econ. Entomol., 104(1): 1-13.

Kalafchi, M.; Mobli, M.; Ebadi, R. and Rezaei, A. M. (2006). A study of population fluctuations of onion thrips (Thrips tabaci Lind.) and its effect on bulbing and yield of selected onion cultivars in Isfahan. Iranian J. Agric. Sci., 36(6): 465-477.

Kanton, R. A. L.; Abbey, L.; Hilla, R. G.;

Tabil, M. A. and Jan, N. D. (2003).

Density Affects Plant

Development and Yield of Bulb

Onion (Allium cepa L.) in

Northern Ghana. Journal of Vegetable Crop Production, 8

2): 15-25.

Karaman, G. A. I. (1970). Studies on certain pests of onion with special reference to their control. M. Sc. Thesis, Fac. Agric., Assiut Univ., Egypt, 170 pp.

Khalil, F. M.; El- Sebae, A. H. and Karaman, G. A. (1971). Some ecological studies on Thrips tabaci 
Lind. Assiut J. Agric. Sci., 2(1): 197-206.

Lorine, I. and Dunicr, V. M. (1988). Population fluctuation of Thrips tabaci Lindeman, (Thysanoptera: Thripidae) on garlic crop. Anis de Sociedade Entom. Do Brasil, 19(2): 367-371.

Lu, F. M. and Lee, H. S. (1987). The life history and seasonal occurrence of onion thrips (Thrips tabaci Lindeman). J. Agric. Res. of China, 36(1): 118-124.

Maher, A. M. and Shafiq, A. M. (2014). Population Dynamics of Onion Thrips, Thrips tabaci, on Onion Cultivars. Journal of Agroecology and Natural Resource Management, 1(3): 141-147.

Maher, A. M.; Shafiq, A. M. and Laisvune, D. (2017). Influence of transplanting date and intercropping on thrips population and production of onion. Scientific Works of the Institute of Horticulture, 36(1-2): 54- 72.

Mahmoud, H. H. (2008). Ecological studies on certain insect pests of onion with special emphasis on the onion bulb fly Eumerus amoenus Loew. (Diptera: Syrphidae). Ph. D. Thesis, Fac. Agric., Cairo Univ., Egypt, 125 pp.

Mahmoud, H. H. (2014). Effect of planting distances, intercropping with onion and varieties on the population of Thrips tabaci Lindeman on garlic in Assiut. J.
Plant Prot. and Path., Mansoura Univ., 5 (4): 393 - 401.

Maksoud, M. A.; Behedi, A. M.; Sherifa Foda, A. E. and Sayed, M. T. (1983). Effect of plant population on germination growth yield and quality of two garlic cultivars in Egypt. J. Hort., 10(2): 143-150.

Massry, S. H. D. (2002). Ecological and biocontrol studies on some pests infesting onion and garlic crops. M. Sc. Thesis, Fac. Agric., Menoufia Univ., Egypt, 162 pp.

McGeary, D. J. (2015). The effects of plant density on the shape, size, uniformity, soluble solids content and yield of onions suitable for pickling. Journal of Horticultural Science, 60: 83-87.

Nasir, M. D.; Faridullah, K. W.; Manhajud-Din, D. and Shah, H. D. (2007). Effect of planting density on growth and yield of onion varieties under climatic conditions of Peshawar. Sarhad J. Agric., 23(4): 911-917.

Nassar, S. H.; Moustapha, S.; Foda, A. S.; Gheta, M. and Ghebrial, S. (1972). A better garlic variety for export. Agric. Res. Rev., 50(4): 47-58.

Neetu, S. and Virendra, K. (2016). Monitoring the infestation and damage level of onion thrips, Thrips tabaci on onion crop in Aligarh (U.P.). Asian Journal of Agriculture \& life Sciences. 1(3): 12-19.

Sabra, I. M.; El-Nagar, M. A. and Shalaby, M. S. I. (2007). Further ecological 
studies on onion pests in Egypt. Egypt. J. Agric. Res., 85(4): 12591266.

Salman, A. M. A. (2000). Relative susceptibility of certain onion varieties to the infestation of the onion thrips, Thrips tabaci Lind. and the onion maggot, Delia alliaria Meigen in Upper Egypt. J. Agric. Sci. Mansoura Univ., 25(1): 469-473.

Shoeib, A. M. and Hosny, M. M. (1972). The distribution of Thrips tabaci Lind. within cotton fields. Bull. Soc. Ent. Egypte, 56: 267-271.

Snedecor, G. W. and Cochran, G. W. (1967). Statistical Methods. The Lowa State Univ. Press. Ames. 534 pp.

Stoffella, P. J.; Cantliffe, D. J. and Damato, G. (2000). Effect of plant density on yield and bulb size of direct sown onions. International Symposium on Timing Field Production in Vegetable Crops. 1: $75 p p$.
Stanislav, T.; Znidar, D.; Vali, N. and Ludvik, R. (2006). Intercropping against onion thrips, Thrips tabaci Lindeman (Thysanoptera: Thripidae) in onion production: on the suitability of orchard grass, lacy phacelia, and buckwheat as alternatives for white clover. Journal of Plant Diseases and Protection, 113(1):24-30.

Tadele, S. and Amin, M. (2014). The Importance and Management Option of Onion thrips, Thrips tabaci (L.) (Thysanoptera: Thripidae) in Ethiopia: A Review. J. Horticulture, 1(2): 1-6.

Xingang Zhou; Gaobo, Yu. And Fengzhi, Wu. (2011). Effects of intercropping cucumber with onion or garlic on soil enzyme activities,microbial communities and cucumber yield. European Journal of Soil Biology 47: 279 287. 
الكثافة العددية لحشرات تربس البصل على البصل وعلاقتها بمسافات الزراعة والتحميل

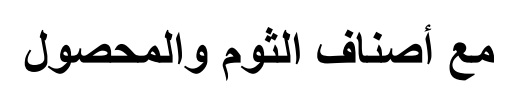

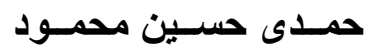

معهر بحوث وقاية النباتات ـ مركز البحوث الزراعية ـ دقى ـ جيزةـــــر مصر

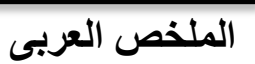

تضمنت هذة الاراسة تاثير بعض العمليات الزراعية مثل مسافات الزراعة (ه ، . 1 , ه1 سم) و تحميل البصل على أصناف الثوم ( المصرى والصينى) وكذلك تاثير أصناف الثوم على تعداد حشرات التربس وذلك خلال

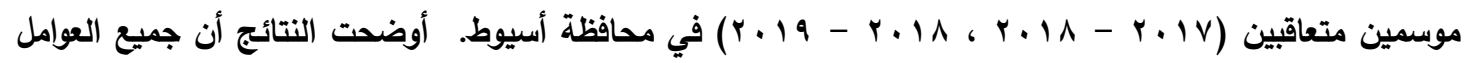
المختبرة كانت مؤثرة بدرجة معنوية على تعداد حشرة التربس في حقول البصل. كما أوضحت النتائج أن مسافات الزراعة كان لها تاثير معنوى جدا على تعداد التربس حيث سجل أعلى تعداد للتربس عند الزراعة على مسافة (ه سم) بين النباتات. كما أظهرت نتائج تحميل البصل على الثوم أن لنباتات الثوم لة تاثير واضح ومعنوى على تعداد حشرة التربس حيث وجد أن متوسط أعداد هذة الافة أنخفضت على نباتات البصل المحملة على الثوم عن تلك المنزرعة منفردا. أيضا وجد أن حشرة تربس البصل لها القدرة على اصابة جميع أصناف الثوم المختبرة ولكن تتفاوت شدة الاصابة من صنف لاخر حيث أظهرت النتائج أن صنف الثوم الصينى سجل أعلى أصابة بالتربس عن الصنف المصرى. كما لوحظ أن اعلى محصول من البصل أعطى عندما كانت المسافة بين التباتات ( • 1 سم) ، كما أدى تحميل البصل مع الثوم الى الحصول على محصول أقل عن البصل المنزرع منفردا وذلك خلال موسمى الدراسة. 